\title{
Subdural haematoma after spinal anaesthesia - do we always need brain computed tomography in post-dural puncture headache? Letter to the Editor
}

\section{Krwiak podtwardówkowy po znieczuleniu przewodowym - czy zawsze potrzebujemy tomografii komputerowej mózgowia w popunkcyjnym bólu głowy? List do Wydawcy}

\author{
Dariusz Kotlęga ${ }^{1,2}{ }^{凶}$, Anna Boczar-Wójcik², Barbara Peda², Przemysław Nowacki ${ }^{1}$ \\ ${ }^{1}$ Pomorski Uniwersytet Medyczny w Szczecinie, Katedra i Klinika Neurologii, ul. Unii Lubelskej 1, 71-252 Szczecin \\ ${ }^{2}$ Głogowski Szpital Powiatowy, Oddział Neurologii, ul. Kościuszki 15, 67-200 Głogów \\ $\triangle$ dkotlega@poczta.onet.pl
}

\section{Dear Editor-in-Chief,}

We would like to indicate a disorder that is very rare, may easily be misdiagnosed, and at the same time provokes diagnostic doubts. We will try to answer the question of whether all patients with post-dural puncture headache have to undergo a brain computed tomography (CT) scan.

As the diagnostic spinal tap is typically used by neurologists and infectious diseases practitioners, spinal anaesthesia is commonly performed in obstetrics, surgery and orthopaedics. There are side-effects that may appear after these interventions, such as post-dural puncture headache, which occurs in approximately $0.4-6 \%$ of procedures [1].

We present a 34-year-old woman that underwent subarachnoid anaesthesia during caesarean section (CC) in $39 \mathrm{Hbd}$ due to the premature rupture of amniotic membranes. There was an administration of bupivacain $4 \mathrm{~mL}$ (Marcaine ${ }^{\circledR}$ Spinal $0.5 \%$ Heavy, solution, $5 \mathrm{mg} / \mathrm{mL}$ ) using a 26-gauge needle after 2 unsuccessful attempts. The day after CC sudden headache and sensation of neck stiffness appeared as the only symptoms. On neurological examination no abnormalities were
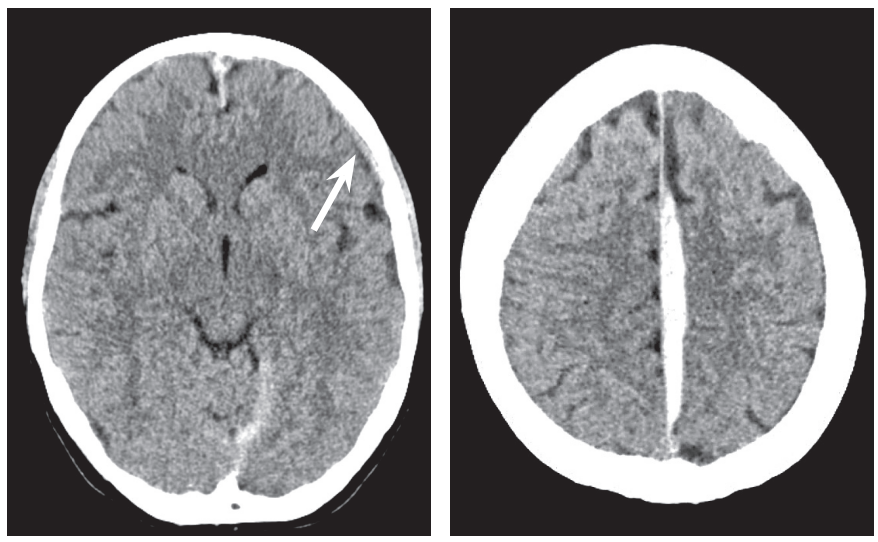

FIGURE 1. Brain computed tomography - subdural haematoma above the left hemisphere
FIGURE 2. Brain computed tomography - subdural haematoma along the falx cerebri

found. Brain CT was performed, which revealed a subdural haematoma above the left hemisphere (frontal, temporal and parietal lobe) up to $5 \mathrm{~mm}$ wide (Figure 1 ) and up to $9 \mathrm{~mm}$ wide along the falx cerebri (Figure 2). In addition the brain CT postinfusion venous scans and CT-angiography were performed without any other abnormalities.

The patient was treated symptomatically without any interventional procedures with resulting with decrease of the headache's severity. 10 days after CC a second brain CT scan was performed with partial resolution of the visualized haematoma - the width was $3 \mathrm{~mm}$ and $6 \mathrm{~mm}$, respectively (Figures 3 and 4). During the whole period of hospitalization no abnormalities were found on neurological examination. Our patient was sent home 11 days after CC without any complaints.

Additional laboratory test results (e.g. coagulation, platelet count) as well as the previous medical history did not reveal any significant pathology that could have provoked the intracranial bleed.

Intracranial subdural haematoma has been a well known disorder since 1658 , and depending on the duration is classified as either acute, subacute or chronic. The main cause is head

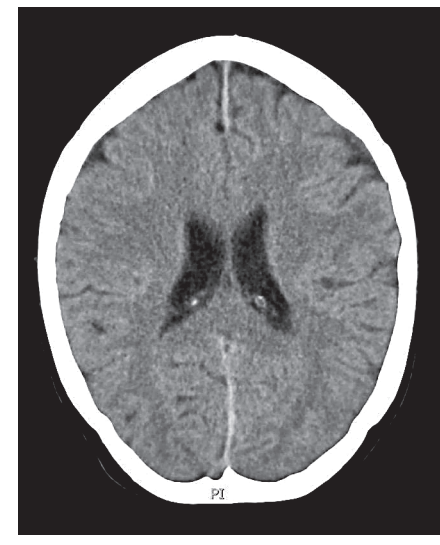

FIGURE 3. Brain computed tomography - regression of lobar subdural haematoma

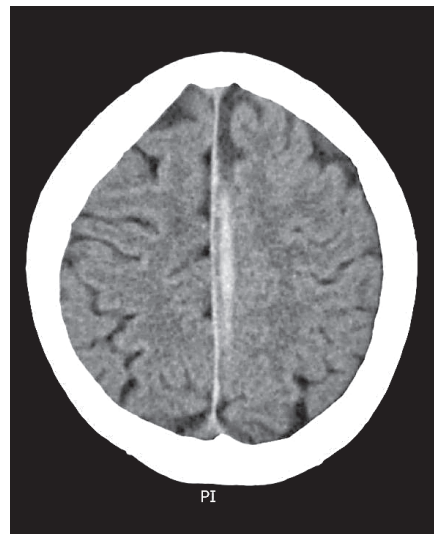

FIGURE 4. Brain computed tomography - regression of falx cerebri subdural haematoma 
trauma in from 50 to $100 \%$ of cases, but less common causes include: coagulation disorders, neurosurgical procedures, dehydration, cancers, and vascular malformations. Haematoma is also known to be a very rare complication of spinal tap or anaesthesia. The main diagnostic procedure besides history and examination is brain CT, but chronic subdural haematomas that may be isodense and difficult to detect require the magnetic resonance imaging examination [2]. Subdural haematoma usually needs a neurosurgical operation, but in some cases conservative treatment is sufficient [3]. This disease may lead to life-threatening and serious sequelae with persistent psychomotor disability. On the other hand, similarly to our patient, there are also cases presenting mainly with subjective symptoms such as headache or tinnitus, without typical neurological findings such as focal neurological symptoms (hemiparesis, aphasia) or consciousness disturbances [4]. In these cases misdiagnosis would not lead to any further negative health complications because conservative treatment alone is sufficient. Of note is the situation presented by other authors when initially mild symptoms such as headache and vomiting were subsequently followed by clinical worsening with speech impairment and limb paresis after 17 days that had to be surgically operated on [5].

Taking into consideration the number of spinal taps and anaesthesia, and the significant percentage of complications presenting as post-dural puncture headache, the question should be raised of whether all patients with the latter should undergo brain CT. The post-dural puncture headache, in opposition to subdural haematoma, is a mild, typically self-limiting disorder. When other possible complications that may also occur after the dural puncture are taken together, such as cerebral venous thrombosis, we suggest considering performing the brain CT more frequently than nowadays in everyday practice [6]. Special attention should be paid to patients after spinal taps suffering from headache or demonstrating deterioration after the lucid interval, which may be indicative of subdural haematoma.

There is insufficient data regarding the potential risk factors of the development of subdural haematoma after the dural puncture. According to the observational studies, we suggest that difficult access with preceding unsuccessful attempts of puncture is the potential risk factor of haematoma occurrence $[7,8]$. This topic should be analysed in further studies.

Yours sincerely, Dariusz Kotlęga, Anna Boczar-Wójcik, Barbara Peda, Przemysław Nowacki

\section{REFERENCES}

1. Skręt-Magierło J, Barnaś E, Sęk-Kłębukowska B, Nicpoń J, Kloc G. Intracranial hematoma as the cause of headache after subarachnoid anesthesia for cesarean section - a case report. Ginekol Pol 2014;85:58-61.

2. Krupa M. Chronic subdural hematoma: A review of the literature. Part 1. Ann Acad Med Stetin 2009;55(2):47-52.
3. Krupa M. Chronic subdural hematoma: A review of the literature. Part 2. Ann Acad Med Stetin 2009;55(3):13-9.

4. Doğanay F, Pirbudak L, Gül R, Alptekin M, Kaplan N. Postspinal subacute subdural hematoma: case report. Agri 2013;25(3):129-32. doi: 10.5505/ agri.2013.76598.

5. Bisinotto FM, Dezena RA, Fabri DC, Abud TM, Canno LH. Intracranial subdural hematoma: a rare complication following spinal anesthesia: case report. Rev Bras Anestesiol 2012;62(1):88-95. doi: 10.1016/S00347094(12)70107-1.

6. Sherfudeen KM, Ramasamy G, Kaliannan SK, Dammalapati PK. Differentiating the headache of cerebral venous thrombosis from post-dural puncture: A headache for anaesthesiologists. Indian J Anaesth 2016;60(5):352-4. doi: 10.4103/0019-5049.181609.

7. Bishop TM, Elsayed KS, Kane KE. Subdural hematoma as a consequence of epidural anesthesia. Case Rep Emerg Med 2015;2015:597942. doi: $10.1155 / 2015 / 597942$.

8. Kale A, Emmez H, Pişkin Ö, Durdağ E. Postdural puncture subdural hematoma or postdural puncture headache?: two cases report. Korean J Anesthesiol 2015;68(5):509-12. doi: 10.4097/kjae.2015.68.5.509.

\section{Diaschisis (glossa)}

\section{Ireneusz Kojder}

Mechanicznie i inaczej warunkowane wielomiejscowe zmiany patologiczne w ośrodkowym układzie nerwowym są bardzo różnorakie. Możemy ich mnogość przypuszczać, bowiem niedoskonałość obrazowania pozwala obecnie ujawnić jedynie wielomiejscowe wybroczyny, zmiany zapalne, niedokrwienia bez możliwości wglądu w mechanizm. Jednakże już dawno były odnotowane. Wystarczy przywołać diaschisis (Monakova) czy skrzyżowany zanik móżdżku (Fredreicha). Ostatnio zainteresowanie budzi współwystępowanie nieprawidłowości struktur i powiązania funkcji móżdżku i mózgu, też w zakresie kognitywnym, nie tylko reologicznie warunkowane. Zjawiska te zasługują na badanie i pozwalają antycypować, jakkolwiek mgliście, ujawnienie nieznanych jeszcze mechanizmów scalających strukturę i funkcje układu nerwowego.

Wylewy wewnątrzczaszkowe powstałe wskutek obniżenia ciśnienia podczas operacji móżdżku czy upustu płynu międzyrdzeniowego dokonanego podpotylicznie czy lędźwiowo znane były neurologom od dawna. Stało się to przyczyną m.in. unikania pozycji siedzącej chorego w czasie operacji neurochirurgicznych jako też warunkowania nakłucia lędźwiowego wyprzedzającą oceną ciasnoty wewnątrzczaszkowej za pomocą badania cech dna oka.

Zasadnym jest, aby mieć na uwadze, iż niejednokrotnie wypływ płynu mózgowo-rdzeniowego do przestrzeni zewnątrztwardówkowej po punkcji lędźwiowej osiąga wielomililitrowe ilości. Tymczasem w dobie łatwo czynionego przewartościowania znaczenia powszechnej dostępności neuroobrazowania dbałość o równowagę ciśnień parcjalnych w różnych przedziałach wewnątrz jamy neuronośnej jest nie dość ceniona. Jest tak nierzadko, gdy przy znieczuleniach dokanałowych nie przewiduje się upustu płynu pozaustrojowo. Fizjologiczne różnice ciśnień parcjalnych wewnątrz i wokół układu nerwowego są bardzo duże, co warunkuje krążenie płynu i ma wpływ na wydajność krążenia krwi. 
W tym zakresie zwłaszcza faza żylna jest poddana dużym zmianom. Znane to od dawna, nie straciło aktualności w odniesieniu do miejsca styku żył zespalających górnych, zwłaszcza w trybie ostrym. Ostatnio też chroniczne upośledzenie odpływu żylnego do zatok podstawy czaszki jest postrzegane jako potencjalnie odpowiedzialne za niektóre choroby układowe i demencje (por. Alzheimer, SM etc.).
Krwiotoczne skutki destabilizacji ciśnień płynu międzyrdzeniowego w poszczególnych częściach układu nerwowego i regionalnego przepływu krwi najłatwiej przywoływane są w wyjaśnieniu mechanizmu odpowiedzialnego przez autorów, którym współczesna gęstość komunikacyjna utrudnia refleksję. 